Biochimica et Biophysica Acta, 369 (1974) 387-396

(C) Elsevier Scientific Publishing Company, Amsterdam - Printed in The Netherlands

BBA 56522

\title{
LIVER AND EXTRAHEPATIC CONTRIBUTIONS TO POSTHEPARIN SERUM LIPASE ACTIVITY OF THE RAT
}

\author{
H. JANSEN and W.C. HÜLSMANN
}

Department of Biochemistry I, Medical Faculty, Erasmus University, P.O. Box 1738, Rotterdam (The Netherlands)

(Received June 26th, 1974)

\section{Summary}

The influence of the amount of heparin injected on the contributions of liver and of extrahepatic tissues to the lipase activity of postheparin serum of the rat was studied. It was found that when high doses of heparin (20 I.U./100 g bodyweight) were injected, the liver contributes for $63 \%$ to the total triacylglycerol lipase activity of postheparin serum. At low heparin levels (0.4 I.U./100 $\mathrm{g}$ bodyweight) the lipase activity in the postheparin serum is almost solely derived from the extrahepatic tissues. The activity of the liver enzyme in the postheparin serum was found to increase very fast after heparin injection. 2 min after heparin injection a maximum activity of the liver enzyme in the serum was found. Subsequently the liver enzyme is removed from the circulation. Not only the activity of the liver enzyme is dependent on the amount of heparin injected, but also the amount of enzyme released from the liver.

Fat feeding increases the hydrolytic activity released from the liver by heparin. Immunological studies suggest that the enzyme may be in a more active state. The role of the heparin-releasable liver enzyme in fat metabolism is discussed.

\section{Introduction}

After intravenous injection of heparin, lipase activity is released into the bloodstream [1]. The enzyme activity is released from different organs. Two species of triacylglycerol lipase activity have been characterized in postheparin serum, differing in substrate specificity and in sensitivity to some inhibitors, such as high concentrations of salt and protamine sulfate $[2,3]$. At least two activities are found to be immunologically different [4] and to be released from liver and extrahepatic organs, respectively [4]. The extrahepatic activity is accepted to be identical with lipoprotein lipase as defined by Korn [5]. The role of this heparin-releasable activity is the hydrolysis of serum triacylglycerols 
$[6,7]$, and therefore involved in the utilization of serum triacylglycerols by these extrahepatic organs. The role of the heparin-releasable liver enzyme is much less clear. Maybe that in vivo the lipase activity of the liver is mainly directed towards fatty acid esters other than triacylglycerols, although the postheparin liver enzyme definitely hydrolyzes serum triacylglycerols in vitro [3]. Indeed, liver releases also phospholipase [8] and monoacylglycerol lipase [9] activities after heparin perfusion. That some lipase and phospholipase activities in postheparin serum may be identical has been suggested already in 1965 by Vogel and Bierman [10]. They showed that in postheparin serum a protein is found with lipase and phospholipase activities which are not separable by electrophoresis, ultracentrifugation or gelfiltration on Sephadex G-200. The liver enzyme may contribute considerably to the overall postheparin serum lipase activity [2-4], the magnitude of which may vary to a large extent. Therefore, we studied some factors that could influence the contribution of the liver lipase activity to the serum, such as the amount of heparin injected and the time of blood collection after heparin injection. Another possible influence studied was the effect of fat feeding since previous work [11] indicated that after 6 days rapeseed oil feeding the lipoprotein lipase activity of postheparin serum is elevated when compared with olive oil feeding. Houtsmuller et al. [12] showed that rapeseed oil feeding results in a maximal triacylglycerol accumulation in rat heart after 3 to 4 days and that after 6 days the triacylglycerol content decreases rapidly. We [11] have, therefore, suggested that the increased postheparin lipase activity found after 6 days feeding might be related to the decrease of the triacylglycerol content of the heart. For that reason we raised the questions: is the increased serum activity after 6 days rapeseed oil feeding of extrahepatic or of hepatic origin and, secondly, is the increased activity due to enzyme activation or an increased synthesis of enzyme protein? Both questions can be answered by immunological studies as will be presented.

\section{Methods}

The lipase activity in the postheparin serum was measured with palmitoyl$\mathrm{CoA}$ or Intralipid as the substrate as described before [13]. In the feeding experiments the rats had free access to water and food unless stated otherwise. The rapeseed oil diet consisted of 50 cal \% rapeseed oil (48\% C22 : 1). The olive oil diet was composed of $50 \mathrm{cal} \%$ olive oil. In contrast to the earlier studies [11] on the connection between lipoprotein lipase and rapeseed oil feeding, the rats were not fasted overnight before use, unless stated different.

In all experiments male Wistar rats were used. Their weights ranged from $210 \pm 30 \mathrm{~g}$. The heparin injections were made intravenously under Nembutal narcosis between 9 and 11 a.m.

Acetonepowders of different organs were prepared as described by Borensztajn et al. [14] and extracted with $25 \mathrm{mM} \mathrm{NH} \mathrm{NH}_{4} \mathrm{OH}-\mathrm{HCl}$ buffer $(\mathrm{pH}$ 8.5). Total hepatectomy was achieved under ethernarcosis by a two-stage procedure. In the first stage $65-75 \%$ of the liver was removed according to Higgins and Anderson [15]. Subsequently a porta-cava shunt was made as described by Fisher and Lee [16]. After the operation the rats were allowed to recover for 
30 min. Then 50 I.U. heparin (Organon, Oss, The Netherlands) were injected intravenously and blood was withdrawn 2 min later.

Differentiation between liver and extrahepatic lipases in postheparin serum

In the postheparin sera the lipase activity released from the liver was determined with the help of an antibody against this activity. The antibody was raised as described previously [4]. The specificity of the antibody was extended to other organs as is shown under Results (Table I). The incubations of the postheparin sera with the antiserum were carried out in principle as described in ref. 4. The incubation temperature, however, was lowered to $0^{\circ} \mathrm{C}$ to avoid inactivation of the extrahepatic enzyme. It was found that during $14 \mathrm{~h}$ of incubation at $0^{\circ} \mathrm{C}$ the total lipase activity of postheparin serum in the absence or presence of serum of a non-immunized rabbit (control serum) was stable. The inhibition by the antiserum was already maximal after about $4 \mathrm{~h}$. The postheparin sera were routinely incubated with an excess of antiserum $(1: 2$, $\mathrm{v} / \mathrm{v}$ ) for $14 \mathrm{~h}$ at $0^{\circ} \mathrm{C}$. An increase of the amount of antiserum or incubation time did not result in a further inhibition of the lipase activity in postheparin serum. After the incubation the mixtures were centrifuged for 2 min at 15000 $X g$ and the activities measured in the supernatant. The amount of lipase activity inhibited is taken as the contribution of the liver to the total lipase activity of the postheparin sera. The rabbit sera used, were always preincubated for $1 \mathrm{~h}$ at $56^{\circ} \mathrm{C}$ in order to inactivate lipase activities possibly present in these sera. In the experiments shown in Fig. 1 and Table VII, antiserum, bound to Sepharose as described by Neuwelt et al. [17], was used.

\section{Estimation of the "specific activity" of the inhibited enzyme}

In order to estimate the "specific activity" of the liver enzyme the enzyme activity that could be bound to Sepharose-linked antiserum was measured. In Fig. 1 a typical experiment is shown. A constant amount of Sepha-

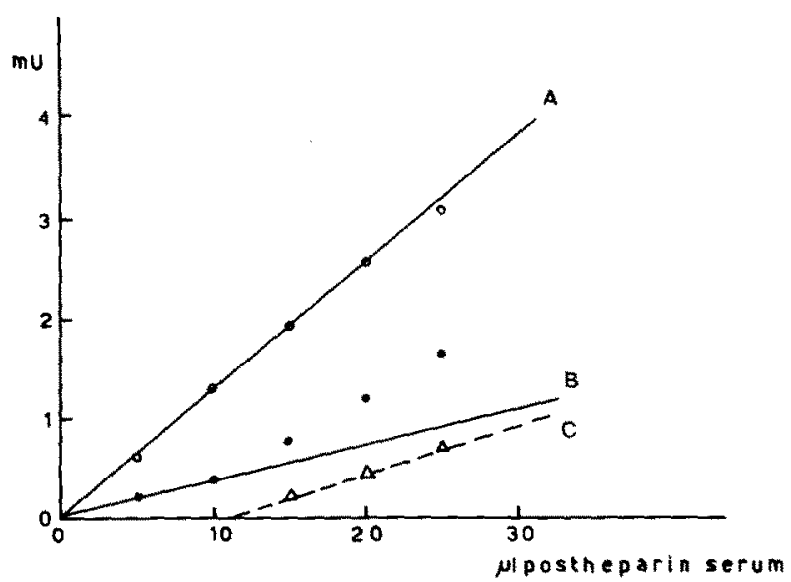

Fig. 1. Relationship between hydrolytic activity and the amount of immunoreactive protein of liver lipase. Each point represents the mean value of duplicate experiments with the serum of a rapeseed oil-fed rat. The experiments were carried out as described under Methods.

* The activity inhibited by a certain amount of antiserum. 
rose-linked antiserum was incubated with different amounts of postheparin serum. The activity of the unbound enzyme was measured in the supernatant after centrifugation at low speed. The measured activity was plotted against the amount of serum incubated (closed circles). In control experiments the same incubations were carried out with Sepharose bound to serum of a nonimmunized rabbit (Line $A$, open circles). Fig. 1 shows that at lower serum concentrations in the presence of a fixed amount of antiserum, the activity increases in a linear fashion with the amount of serum added. This activity must be of extrahepatic origin. At higher serum concentrations, however, the antiserum is saturated with the enzyme of hepatic origin and therefore the latter as well as enzyme(s) of extrahepatic origin will contribute to the activity, so that an upward inflection can be observed (Fig. 1, closed circles). By extrapolation of the initial part of the curve (Line B) and subtraction of the calculated extrahepatic activities from the activities measured at higher serum concentrations (closed circles), a curve can be constructed (Line C), which presents the activity of the hepatic contribution at the serum concentration plotted on the abscissa. By extrapolation of Line $\mathrm{C}$ an intersection with the abscissa is obtained, the value of which represents the maximal amount of serum of which all (liver) activity is bound by the amount of antibody used. The corresponding (liver) activity of that amount of serum can be calculated.

\section{Results}

\section{Specificity of the antiserum}

In order to test the specificity of the antisera, lipase activities of acetonepowder extracts of different organs were measured after preincubation with serum of a non-immunized rabbit (control serum) or antiserum. In Table I it can be seen that while the liver activity is completely inhibited, the lipase activities of the other organs are not influenced by the antiserum. Previously [4] we reported that also the lipase activity of in vitro obtained perfusates of rat liver was abolished completely by the antiserum, while heart perfusates were unaffected. In order to study also the in vivo released lipase activities of extrahepatic organs, two rats were hepatectomized as described under Methods.

TABLE I

INHIBITION OF LIPASE ACTIVITIES FROM DIFFERENT SOURCES BY THE ANTISER UM

Acetonepowder extracts of different organs were diluted with buffer so that every extract contained the sant order of lipase activity per ml. Then the extracts were incubated with control-or antiserum. Lipase activities were measured with Intralipid as the substrate and expressed in nmoles free fatty acid released min per ml extract.

\begin{tabular}{llc}
\hline Enzyme source & \multicolumn{2}{c}{ Activity after incubation with } \\
\cline { 2 - 3 } & Control serum & Antiserum \\
\hline Liver & 14 & 0 \\
Lung & 28 & 28 \\
Heart & 34 & 33 \\
Adipose tissue & 27 & 28 \\
\hline
\end{tabular}


It was found that the antiserum did not influence the lipase activity of the serum of these rats after injection of $50 \mathrm{I} . \mathrm{U}$. heparin when either palmitoylCoA or Intralipid was used as the substrate. From these data it is concluded that the antiserum is inactive against extrahepatic lipases and that the activity released from the liver is completely inhibited.

Influence of the amount of heparin injected and time of bloodremoval on postheparin lipase activity of hepatic origin

The influence of the amount of heparin injected on the contributions of the liver and extrahepatic organs to the total serum triacylglycerol hydrolase activity is shown in Table II. Apparently the activity displayed by the liver enzyme depends on the amount of heparin injected. The extrahepatic contribution seems to be released at lower heparin concentrations and relatively little influenced by the injection of the higher heparin concentrations. In these experiments blood was withdrawn 2 min after heparin injection. Earlier we have found with isolated perfused rat liver that the bulk of the heparin-releasable activity is released within $2 \mathrm{~min}$. From the experiments of Table III it can be concluded that indeed in the intact rat also, the hepatic contribution to the total serum activity is higher at $2 \mathrm{~min}$ after the injection of 50 I.U. heparin than at $6 \mathrm{~min}$ and that the hepatic contribution beyond this time declines significantly. This contrasts the extrahepatic contribution which remains relatively constant between 2 and $20 \mathrm{~min}$ after injection. A similar picture was obtained when the lipase activity in the serum was tested with palmitoyl-CoA as the substrate (ref. 13) instead of trioleylglycerol (cf. also Table IV). With palmitoyl-CoA as the substrate the liver contribution to the hydrolytic activity of postheparin serum was much larger than with trioleylglycerol as the substrate (compare Tables III and IV) In other words, the hepatic contribution to postheparin serum lipase can hydrolyse both palmitoyl-CoA and trioleate efficiently, whereas the extrahepatic contribution preferentially hydrolyses trioleylglycerol and has little activity towards palmitoyl-CoA. In a large series of experiments the latter could be verified (not shown).

TABLE II

INFLUENCE OF THE AMOUNT OF HEPARIN INJECTED ON THE CONTRIBUTIONS OF LIVER AND OTHER ORGANS TO THE LIPASE ACTIVITY IN POSTHEPARIN* SERUM

Four groups of five rats were injected intravenously with 1, 5, 25 or 50 I.U. heparin, respectively. 2 min after the injection the rats were killed and the blood collected. In the serum the contributions of the liver and extrahepatic organs to the total lipase activity was estimated as described under Methods. Lipase activity was measured with "Intralipid" as the substrate. The activities are expressed in nmoles free fatty acid released/min per $\mathrm{ml} \pm \mathrm{S}$.E.

\begin{tabular}{|c|c|c|c|}
\hline \multirow{2}{*}{$\begin{array}{l}\text { Amount } \\
\text { of heparin } \\
\text { injected }\end{array}$} & \multicolumn{2}{|c|}{ Lipase activity } & \multirow{2}{*}{$\begin{array}{l}\text { Percentage } \\
\text { liver- } \\
\text { activities }\end{array}$} \\
\hline & Hepatic & Extrahepatic & \\
\hline 1 & $2 \pm 2$ & $65 \pm 17$ & 3 \\
\hline 5 & $55 \pm 8$ & $80 \pm 14$ & 41 \\
\hline 25 & $172 \pm 14$ & $120 \pm 16$ & 59 \\
\hline 50 & $200 \pm 15$ & $115 \pm 7$ & 63 \\
\hline
\end{tabular}

* The lipase activity of preheparin rat serum were found to be negligible. 
TABLE III

INFLUENCE OF THE TIME OF BLOOD WITHDRAWAL AFTER HEPARIN INJECTION ON THE CONTRIBUTIONS OF THE LIVER AND EXTRAHEPATIC ORGANS TO THE TOTAL LIPASE ACTIVITY IN POSTHEPARIN SERUM

Five rats were injected with $50 \mathrm{1} . \mathrm{U}$. of heparin. $1 \mathrm{ml}$ of blood was withdrawn from each rat at 2.6 and 20 min after the heparin injection. In the sera the contributions of the liver and the extrahepatic organs to the total lipase activity of the serum was estimated as described under Methods. "Intralipid" was the substrate. The activity is expressed as nmoles free fatty acid released $/ \mathrm{min}$ per $\mathrm{ml} \pm \mathrm{S}$.E.

\begin{tabular}{|c|c|c|c|}
\hline \multirow{2}{*}{$\begin{array}{l}\text { Blood withdrawn } \\
\text { after heparin } \\
\text { injection }(\mathrm{min})\end{array}$} & \multicolumn{2}{|c|}{ Lipase activity } & \multirow{2}{*}{$\begin{array}{l}\text { Contribution of the } \\
\text { liver to the total } \\
\text { lipase activities }(\%)\end{array}$} \\
\hline & Hepatic & Extrahepatic & \\
\hline 2 & $194 \pm 16$ & $116 \pm 14$ & 63 \\
\hline 6 & $165 \pm 7$ & $118 \pm 13$ & 60 \\
\hline 20 & $99 \pm 14$ & $106 \pm 11$ & 48 \\
\hline
\end{tabular}

From Tables II and III it can be concluded that when relatively high concentrations of heparin are used a large part of the postheparin lipolytic activity is of hepatic origin and that the activity rapidly decreases when the removal of blood from the animal is delayed. Subsequently we investigated whether the disappearance of the activity from the bloodstream is due to inactivation of the enzyme, i.e. whether the ratio of active vs. inactive enzyme in the blood would decline, or whether enzyme protein active or inactive would disappear from the bloodstream by e.g. uptake in the liver (compare refs. 21 and 22). Therefore, rats were injected with different amounts of heparin and blood removed at different times. It can be seen from Table IV that delayed removal of blood causes a decrease of the liver contribution to postheparin lipolytic activity and that the amount of antiserum required to inhibit one munit of enzyme activity remains fairly constant. This indicates that enzyme protein completely disappears from the bloodstream and that not inactive,

TABLE IV

PALMITOYL-COA HYDROLASE ACTIVITY IN POSTHEPARIN RAT SERA; INFLUENCE OF RABBIT ANTI RAT LIVER SERUM

Rats were injected with either 50 I.U. or 20 I.U. heparin as indicated. Blood was withdrawn at various times after the injection. In the sera the hepatic palmitoyl-CoA hydrolase activity was estimated as described under Methods. By varying the antiserum concentration at a constant rat serum concentration the amount of antiserum that inhibited $50 \%$ of the liver activity was estimated. From the data obtained the palmitoyl-CoA nydrolase activity that was inhibited by $1 \mu \mathrm{l}$ antiserum was calculated. Activities are expressed in nmoles CuASH released $/ \mathrm{min}$ per $\mathrm{ml}$.

\begin{tabular}{|c|c|c|c|c|}
\hline \multirow{2}{*}{$\begin{array}{l}\text { Heparin } \\
\text { injection } \\
\text { (I.U.) }\end{array}$} & \multirow{2}{*}{$\begin{array}{l}\text { Blood with- } \\
\text { drawn after } \\
\text { (min) }\end{array}$} & \multicolumn{2}{|l|}{ Hydrolase activity } & \multirow{2}{*}{$\begin{array}{l}\text { Activity } \\
\text { inhibited } \\
\text { by } 1 \mu 1 \\
\text { antiserum } \\
\text { (munits) }\end{array}$} \\
\hline & & Hepatic & Extrahepatic & \\
\hline \multirow[t]{2}{*}{50} & 2 & 281 & 18 & 0.32 \\
\hline & 30 & 162 & 28 & 0.33 \\
\hline \multirow[t]{2}{*}{20} & 2 & 120 & 21 & 0.33 \\
\hline & 20 & 52 & 20 & 0.30 \\
\hline
\end{tabular}


TABLE V

CONTRIBUTIONS OF LIVER AND EXTRAHEPATIC ORGANS TO THE HYDROLASE ACTIVITY OF POSTHEPARIN SERUM OF RATS FED ON VARIOUS DIETS AFTER A 16-h FASTING PERIOD

Rats were fed during 10 days on various diets (see under Methods). After this period the rats were fasted for $16 \mathrm{~h}$. Then heparin was injected intravenously (10 I.U./100 g body weight). After $6 \mathrm{~min}$ blood was withdrawn. Hepatic and extrahepatic contributions were estimated as described under Methods. Activities are expressed in nmoles palmitoyl-CoA hydrolyzed $/ \mathrm{min}$ per $\mathrm{ml}$ serum \pm S.E.

\begin{tabular}{|c|c|c|c|c|}
\hline \multirow[t]{2}{*}{ Diet } & \multirow{2}{*}{$\begin{array}{l}\text { Number } \\
\text { of rats }\end{array}$} & \multicolumn{3}{|c|}{ Hydrolase activity in the serum } \\
\hline & & Total & Hepatic & Extrahepatic \\
\hline Laboratory chow & 4 & $147 \pm 7$ & $105 \pm 5^{a}$ & $42 \pm 2^{d}$ \\
\hline Olive oil & 6 & $139 \pm 13$ & $107 \pm 11^{b}$ & $32 \pm 2^{e}$ \\
\hline Rapeseed oil & 7 & $180 \pm 10$ & $140 \pm 8^{c}$ & $40 \pm 2^{f}$ \\
\hline
\end{tabular}

Statistically significant difference between a and $\mathrm{c}: 0.02>P>0.01$, between $\mathrm{b}$ and $\mathrm{c}: 0.025>P>$ 0.02 , between $d$ and e: $0.05>P>0.025$, e and $\mathrm{f}: 0.05>P>0.025$.

Not significantly different are $a$ and $b$ nor $d$ and $f$.

immuno-reactive enzyme protein gradually increases in the blood. In these experiments we determined the amount of antiserum required to inhibit $50 \%$ of the liver enzyme activity, as described in Table IV.

\section{Influence of fat feeding on liver lipase activity in postheparin serum}

Rats were fed a rapeseed oil-rich or an olive oil-rich diet for 10 days. The rats were fasted for $24 \mathrm{~h}$ and subsequently injected intravenously with $10 \mathrm{I} . \mathrm{U}$. heparin per $100 \mathrm{~g}$ bodyweight. 6 min later blood was withdrawn to prepare the postheparin serum in which lipolytic activity was assayed. Table $\mathrm{V}$ shows that in accordance with earlier observations [11] the total lipase activity in the postheparin serum of the rapeseed oil-fed rats is higher than that of the olive oil-fed rats or of the control rats. From the second and third columns of this table it appears that this elevation is mainly due to increased liver enzyme activity and that the total contribution of the extrahepatic organs to serum palmitoyl-CoA hydrolase activity remains fairly constant. It is known that the state of nutrition may influence the heparin-releasable lipase activity. The same experiment was therefore repeated without fasting the rats before the injection of heparin. The results are shown in Table VI. Clearly the activities of the liver

TABLE VI

CONTRIBUTIONS OF LIVER AND EXTRAHEPATIC ORGANS TO THE HYDROLASE ACTIVITY OF POSTHEPARIN SERUM OF RATS FED ON VARIOUS DIETS

Conditions as in Table IV, but without fasting before the heparin injection.

\begin{tabular}{|c|c|c|c|c|}
\hline \multirow[t]{2}{*}{ Diet } & \multirow{2}{*}{$\begin{array}{l}\text { Number } \\
\text { of rats }\end{array}$} & \multicolumn{3}{|c|}{ Hydrolase activity in the serum } \\
\hline & & Total & Hepatic & Extrahepatic \\
\hline Laboratory chow & 2 & $224 \pm 20$ & $172 \pm 10^{\mathrm{a}}$ & $52 \pm 10$ \\
\hline Olive oil & 4 & $268 \pm 22$ & $229 \pm 15^{b}$ & $39 \pm 7$ \\
\hline Rapeseed oil & 4 & $286 \pm 12$ & $235 \pm 9 c$ & $51 \pm 3$ \\
\hline
\end{tabular}


TABLE VII

"SPECIFIC ACTIVITIES" OF THE LIVER HYDROLASE ACTIVITY IN POSTHEPARIN SERUM OF RAPESEED OIL AND OLIVE OIL-FED RATS

The amount of postheparin serum, in which hydrolase activity was inhibited by a fixed amount of antiserum ("specific activity"), was estimated as described under Methods. The same sera were used as in Table $V$. The activity inhibited by the fixed amount of antiserum was calculated and expressed in munits (nmoles CoASH liberated/min). Palmitoyl-CoA was the substrate.

\begin{tabular}{lcc}
\hline Diet & Liver hy drolase activity inhibited by a fixed amount of antiserum (munits) \\
\cline { 2 - 2 } & Expt I & Expt II \\
\hline Rapeseed oil & 1.97 & 1.94 \\
Olive oil & 1.31 & 1.32 \\
\hline
\end{tabular}

enzymes from rapeseed oil- or olive oil-fed rats are equal, but significantly higher than from rats fed with a normal laboratory chow diet.

In order to obtain some insight in the mechanism of the activation of the liver enzyme we estimated whether the higher activity of the liver lipase in the rapeseed oil-fed rats (Table $\mathrm{V}$ ) was due to more enzyme or to a more active enzyme. Table VII demonstrates that the same quantity of antiserum binds more activity in the rapeseed oil-fed rats than in the olive oil-fed rats. From this it could be concluded that the elevation of activity in the rapeseed oil-fed rats is due to a more active enzyme. Both Tables $\mathrm{V}$ and VI suggest that feeding rats with an olive oil-rich diet results in low extra hepatic palmitoyl-CoA hydrolase activity. That this could possibly reflect a low (extra-hepatic) lipoprotein lipase activity is suggested in experiments presented elsewhere [18], in which olive oil-rich feeding also results in low cardiac triacylglycerol hydrolysing activity.

\section{Discussion}

In this paper it is shown that the relative contribution of liver and extrahepatic organs to the postheparin lipase activity of serum strongly depends on the dosis of heparin injected (Table II) and the time of removal of blood from the animal (Table III). Whereas the extrahepatic organs may remove triacylglycerols from the serum $[6,7]$, for which their lipoprotein lipase activity at the capillary lining may be essential, the liver is thought mainly to contribute to the formation of serum triacylglycerols (as very-low-density lipoproteins) and not to their utilization. Yet the liver, especially when high concentrations of heparin are injected, contributes to a large extent to the serum lipase activity (ref. 4 and Tables II-IV of the present paper). Probably then the high liver activity against triacylglycerols does not represent the capacity of the liver to hydrolyse these substrates in vivo. It should be noted that the high liver activities are measured when high doses of heparin are injected. These high doses are highly unphysiologically. Condon et al. [19] found that after hepateclomy of dogs the release of lipolytic activity by heparin into the serum was somewhat retarded, when compared to control dogs. That the same may hold for rats can be seen from Tables III and IV. We found that the hepatic contribution is removed from the serum more rapidly after heparin injection than the extra- 
hepatic contribution. The liver enzyme is completely removed from the serum and not inactivated while still being in the serum (Table IV). What happens to the lipase activity when removed from the circulation is not clear. Whether the activity remains operative or is inactivated has to be investigated. The place where the lipase is removed from the serum is not known although evidence has been brought forward that it may be the liver $[21,22]$.

From the data shown in Table $\mathrm{V}$ it can be seen that fat feeding enhances the heparin-releasable lipase activity of hepatic origin in postheparin serum. The activity of extrahepatic origin is slightly lowered by olive oil feeding and significantly after fasting (Tables V and VI). This may be of considerable importance since lipoprotein lipase activity may be involved in atherogenesis (Zilversmit [23], Hülsmann and Jansen [24]) and hence deserves more documentation. In contrast to the lipase activity of the rat heart (ref. 18) the elevation of the liver lipase activity is independent whether erucic acid (C22 : 1; a major component of rapeseed oil) is the major acid or not (Table VI). In the fasted state, however (Table V), the liver lipase of the rapeseed oil-fed rats remains at a higher level than that of the olive oil- or chow-fed rats. Whether the difference in liver lipase activity in the fasted state must be attributed to a direct effect of different fatty acids or to a secondary effect cannot be concluded yet. A possible explanation may be that after rapeseed oil feeding, due to the prolonged alimentary lipemia after rapeseed oil digestion [26], the animals are in a less fasted state than other animals. Of interest is the observation that the higher activity of the liver enzyme is not due to more enzyme but to a more active enzyme (Table VII). The factor that determines the activity of the liver is unknown. One possibility is that the enzyme is normally present in both active and inactive forms and that the equilibrium is shifted to the more active state in the (rapeseed) oil-fed rats. Another simple explanation may be the stabilization of the enzyme by triacylglycerols. The role of the liver lipase activity in the overall triacylglycerol metabolism remains uncertain, but may be involved in the degradation of low- and high-density lipoproteins (compare Introduction).

From the presented data (Tables III and IV) it is concluded that the palmitoyl-Co $\Lambda$ hydrolase activity in postheparin serum is mainly of hepatic origin, a conclusion already reached earlier by us [4]. This illustrates the different substrate specificities of the various postheparin serum hydrolases (compare also ref. 25). Whether the lipolytic activities released from the liver by heparin perfusion are due to the release of one enzyme or due to the release of phospholipase [8,10,20], monoacylglycerol lipase [9], palmitoyl-CoA hydrolase and triacylglycerol lipase as separate enzymes, with perhaps overlapping substrate specificity, requires further investigation. The choice of substrate by the in vitro estimation may influence the relative contributions of liver and extrahepatic enzymes considerably. Therefore, no direct conclusions of the in vivo capability of different organs in the hydrolysis of endogenous substrates may be drawn from the activities measured in postheparin serum in vitro. From this paper it becomes clear that the amount of heparin and the time of blood removal may influence the activities in postheparin serum. 


\section{Acknowledgements}

We wish to thank Mrs A. van Zuylen-van Wiggen for expert technical assistance. Mr W.J. Kort of the Department of Experimental Surgery of our University is thanked for carrying out the functional hepatectomies of rats. Dr U.M.T. Houtsmuller (Unilever Research, Vlaardingen) is gratefully thanked for help and advice. This investigation was carried out under the auspices of the Netherlands Foundation for Chemical Research (S.O.N.) and with financial aid from the Netherlands Organization for the Advancement of Pure Scientific Research (Z.W.O.).

\section{References}

1 Hahn, P.F. (1943) Science 19-20

2 LaRosa, J.C., Levy, R.I., Windmueller, H.G. and Fredrickson, D.S. (1972) J. Lipid Res. 13, 356-363

3 Kraus, R.M., Windmueller, H.G., Levy, R.I. and Fredrickson, D.S. (1973) J. Lipid Res. 14, 286-295

4 Jansen, H., van Zuylen-van Wiggen, A., Hülsmann, W.C. (1973) Biochem. Biophys. Res. Commun. 55 , $30-37$

5 Korn, E.D. (1955) J. Biol. Chem. 215, 1-14

6 Robinson, D.S. and Jennings, M.A. (1965) J, Lipid Res. 6, 222-227

7 Scow, R.O., Hamosh, M., Blanchette-Mackie, E.J. and Evans, A.J. (1972) Lipids 7, 497-505

8 Zieve, F.J. and Zieve, L. (1972) Biochem. Biophys. Res. Commun. 47, 1480-1485

9 Fielding, C.J. (1972) Biochim. Biophys. Acta 280,569-578

10 Vogel, W.C. and Bierman, E.L. (1965) Fed. Proc. 24, 439

11 Struyk, C.B., Houtsmuller, U.M.T., Jansen, H. and Hülsmann, W.C. (1973) Biochim. Biophys. Acta $296,253 \rightarrow 256$

12 Houtsmuller, U.M.T., Struyk, C.B. and van der Beek, A. (1970) Biochim. Biophys. Acta 218 , $564-566$

13 Jansen, H. and Hülsmann, W.C. (1973) Biochim. Biophys. Acta 296, 241-248

14 Borensztajn. J., Otway, S. and Robinson, D.S. (1970) J. Lipid Res. 11, 102-110

15 Higgins, G.M. and Anderson, R.M. (1931) Arch. Pathol. 12, 186--202

16 Fisher, B. and Lee, S. (1965) Surgery 58, 904-914

17 Neuwelt, E., Kohler, P.F. and A ustin, J. (1973) Immunochemistry 10, 767-773

18 Jansen, H., Hülsmann, W.C., Struyk, C.B. and Houtsmuller, U.M.T. (1974) submitted for publication

19 Condon, R.E., Tobias, H. and Datta, D.V. (1965) J. Clin. Invest. 44, 860-869

20 Waile, M. and Sisson, P. (1973) J. Biol. Chem. 248, 7201-7206

21 Conner, W.E. and Eckstein, J.W. (1959) J. Clin. Invest. 38, 1746-1755

22 Constantinides, P., So, Y. and Johnstone, F.R.C. (1959) Proc. Soc. Exp. Biol. 99, 262-264

23 Zilversmit, D.B. (1973) Circ. Res. 33, 633-636

24 Hülsmann, W.C. and Jansen, H. (1974) Lipmann Symposium: Energy, Biosynthesis and Regulation in Molecular Biology (Richter, D., ed.), pp, 322-335, De Gruyter, Berlin

25 Biale, Y. and Shafrir, E. (1969) Clin. Chim. Acta 23, 413-419

26 Thomasson, H.J., MacDuinald, I, and van der Beek, A. (1971) Nutr. Metab. 13, 178-185 